Article

\title{
Ameliorative Effects of Antibiotic-, Probiotic- and Phytobiotic-Supplemented Diets on the Performance, Intestinal Health, Carcass Traits, and Meat Quality of Clostridium perfringens-Infected Broilers
}

\author{
Elsayed O.S. Hussein ${ }^{1, *} \mathbb{0}$, Shamseldein H. Ahmed ${ }^{2}$, Alaeldein M. Abudabos ${ }^{1}$, \\ Gamaleldin M. Suliman ${ }^{1}\left(\mathbb{D}\right.$, Mohamed E. Abd El-Hack ${ }^{3} \mathbb{D}$, Ayman A. Swelum ${ }^{1,4}{ }^{(D)}$ and \\ Abdullah N. Alowaimer ${ }^{1}$ \\ 1 Department of Animal Production, College of Food and Agriculture Sciences, King Saud University, \\ P.O. Box 2460, Riyadh 11451, Saudi Arabia; aabudabos@ksu.edu.sa (A.M.A.); \\ gsuliman@ksu.edu.sa (G.M.S.); aswelum@ksu.edu.sa (A.A.S.); aowaimer@ksu.edu.sa (A.N.A.) \\ 2 Department of Basic Sciences, College of Veterinary Medicine, Sudan University of Science and Technology, \\ Khartoum 12942, Sudan; shamshahmed@yahoo.com \\ 3 Poultry Department, Faculty of Agriculture, Zagazig University, Zagazig 44511, Egypt; \\ dr.mohamed.e.abdalhaq@gmail.com \\ 4 Department of Theriogenology, Faculty of Veterinary Medicine, Zagazig University, Zagazig 44511, Egypt \\ * Correspondence: shessin@ksu.edu.sa; Tel.: +96-(65)-4020-3011
}

Received: 26 February 2020; Accepted: 10 April 2020; Published: 12 April 2020

check for updates

Simple Summary: Necrotic enteritis is considered the most important economic problem for the poultry industry due to the sudden death rates of up to $50 \%$. However, there is limited information concerning the ameliorative role of probiotic and/or phytobiotic compounds in the prevention of Clostridium perfringens infections in broilers. Hence, this trial is conducted to evaluate the influence of some antibiotic, probiotic and phytobiotic compounds (Maxus, CloStat, Sangrovit Extra, CloStat + Sangrovit Extra, and Gallipro Tect) on the growth performance, carcass traits, intestinal health, and meat quality of broiler chicks. The obtained in vivo results highlight that a probiotic- and/or phytobiotic-supplemented diet has many positive effects on the performance, organ weight, and meat quality of broilers. Besides, a notable reduction in the lesion score is observed with a combined probiotic and phytobiotic diet.

Abstract: The poultry industry needs efficient antibiotic alternatives to prevent necrotic enteritis (NE)
infections. Here, we evaluate the effects of probiotic and/or prebiotic dietary supplementation on
performance, meat quality and carcass traits, using only an NE coinfection model, in broiler chickens.
Three hundred and twenty-four healthy Ross 308 broiler chicks are allocated into six groups. Taking a
$35 \mathrm{~d}$ feeding trial, the chicks are fed a basal diet with $0.0,0.1,0.5,0.12,0.5+0.12$, and $0.2 \mathrm{~g} \mathrm{Kg}^{-1}$ for the
control ( $\left.\mathrm{T}_{1}\right)$, Avilamycin (Maxus; $\left.\mathrm{T}_{2}\right)$, live probiotic $\left(\mathrm{CloStat}\left(\right.\right.$ Bacillus subtilis); $\left.\mathrm{T}_{3}\right)$, natural phytobiotic
compounds (Sangrovit Extra (sanguinarine and protopine); $\left.\mathrm{T}_{4}\right), \mathrm{CloStat}+$ Sangrovit Extra $\left(\mathrm{T}_{5}\right)$, and
spore probiotic strain (Gallipro Tect (Bacillus subtilis spores); $\left.\mathrm{T}_{6}\right)$ treatments, respectively. Occurring
at 15 days-old, chicks are inoculated with Clostridium perfringens. The obtained results reveal that all
feed additives improve the performance, feed efficiency, and survival rate, and reduces the intestinal
lesions score compared with the control group. The $\mathrm{T}_{6}$ followed by $\mathrm{T}_{3}$ groups show a significant
( $p<0.05$ ) increase in some carcass traits, such as dressing, spleen, and thymus percentages compared
with other treatments. Also, $\mathrm{T}_{5}$ and $\mathrm{T}_{6}$ have significantly recorded the lowest temperature and pHu
values and the highest hardness and chewiness texture values compared to the other treated groups.
To conclude, probiotics combined with prebiotic supplementation improves the growth, meat quality,
carcass characterization and survival rate of NE-infected broiler chickens by modulating gut health 
conditions and decreasing lesion scores. Moreover, it could be useful as an ameliorated NE disease alternative to antibiotics in $C$. perfringens coinfected poultry.

Keywords: probiotic; Clostridium perfringens; phytobiotic; broiler

\section{Introduction}

Clostridium perfringens is a Gram-positive bacterium which is common within ecosystems and healthy intestinal microflora [1]. C. perfringens is responsible for several diseases in humans, wildlife, and farm animals [2], and is the leading cause of necrotic enteric (NE) disease in farm animals, especially in poultry [3]. Regarding birds, NE disease is caused by specific strains of $C$. perfringens. It costs the global poultry industry over two billion dollars annually, mainly due to the high costs of antibiotics and inactive feed conversion $[4,5]$. Several studies have reported that $C$. perfringens bacteria could produce more than 15 different toxins [6,7]. Although all C. perfringens types can induce $\alpha$-toxin [3], this kind of toxin causes serious enteric and intestinal diseases in animals and humans [8]. Infected birds show severe lesions of the jejunum and ileum, with the small intestine presenting a degenerated mucosa and is distended by gases produced by C. perfringens [9]. Signs of infection include depression, reduced mobility, and diarrhoea, which is the most visibly obvious symptom [10].

Several strategies are commonly used to alleviate the symptoms of enteritis in broilers, including the use of probiotics [11]. It has been recognized that administering antibiotics as feed additives can avoid mortalities induced by NE [12]. Avilamycin is an antibiotic of the oligosaccharides family and is widely active against Gram-positive bacteria [13]. Moreover, Avilamycin has been shown to have potent bactericidal effects on C. perfringens in vitro [11]. Similar results were found by Paradis et al. [11] and Mwangi et al. [14], who reported linear relationships between the level of Avilamycin in the feed and a reduction in NE mortalities, NE lesion scores, and intestinal C. perfringens count.

A probiotic is a live microbial feed supplement which beneficially affects the host animal by improving its intestinal microbial balance [15-17]. Probiotics can interact with the host to improve immunity and intestinal morphology or stimulate the metabolism, thus reducing the risk of infection by opportunistic pathogens [18]. Probiotic bacteria also have been shown to produce molecules with antimicrobial activities, such as bacteriocins, which target specific pathogens or inhibit the adhesion of pathogens or the production of pathogenic toxins [19,20]. Moreover, beneficial bacteria can act as competition against pathogenic strains within the host [21]. A large number of studies have described the isolation of some strains belonging to the genera Bacillus and Lactobacillus, which exhibit anti-C. perfringens activity in vitro [22,23]. The supplementation of animal feed with Bacillus spores (B. licheniformis) also was tested and proven to be an efficient alternative to antibiotics when used in larger amounts and for longer periods [24]. When 20 day-old chicks, inoculated with low amounts of $C$. perfringens, were given a single dose of $10^{9}$ B. subtilis spores, the colonization and persistence of $C$. perfringens were abolished. However, the B. subtilis strain alone was unable to affect $C$. perfringens in vitro [25]. Also, Sokale et al. [26] reported that using Bacillus subtilis as a feed supplement in broiler chicks increased the performance and reduced mortality in the chicks treated with $C$. perfringens. The supplementation of $B$. subtilis not only controlled C. perfringens-induced NE, but also improved the intestinal health of the broilers [27].

Several natural products such as herbs, spices and essential oils are categorized under the term botanic, phytobiotic or phytogenic compounds [28-30]. Phytobiotics are well identified for their antibacterial and pharmacological effects and, thus, are commonly used in broiler feed as growth promoters and alternative medicines [17]. A huge number of in vitro and in vivo studies have approved a varied range of activities for phytobiotics in poultry nutrition, like stimulation of feed intake, or antimicrobial, coccidiostatic, anthelmintic and immunostimulating actions [31]. Abudabos et al. [32] reported that using Sanguinarine as a feed supplement in broiler chicks (Ross 308) challenged with Clostridium perfringens enhanced performance, carcass traits and some blood biochemical parameters. Also, El-Sheikh et al. [33] 
informed that the prebiotic supplemented (Sanguinarine) diet could be an effective treatment alternative to antibiotics for controlling necrotic enteritis diseases in broilers. Diverse types of additives include phytobiotics (primary or secondary components of plants that contain bioactive compounds that exert a positive effect on the growth and health of animals) which could be a beneficial strategy that regulates the gastro-intestinal microbial community and improve broiler health [34].

Found in the literature, the positive effects of both B. subtilis and phytobiotic compounds have been reported. However, their synergistic effects have not been described yet. The present study aims to evaluate the ameliorative effects of probiotic and phytobiotic compounds alone or in a combined form of two different types of $B$. subtilis on the performance, carcass traits, meat measurements, and intestinal health of $C$. perfringens-infected broilers during the starter and finisher phases.

\section{Materials and Methods}

The experiment was performed in cage pens under similar managerial and hygienic conditions in an environmentally controlled poultry unit at the Animal Production Department, College of Food Science and Agriculture Science, King Saud University. All protocols were chosen according to the experimentation guidelines of the Animal Use Ethics in Research Committee of King Saud University (approval number: SE-19-150).

\subsection{Experimental Design and Feeding Regime}

Altogether, 324 day-old broiler chicks (Ross 308 strain) were randomly distributed into six groups. Each group contained nine replicates, with six birds per replicate, and were used for a $35 \mathrm{~d}$ feeding trial period. Each group was assigned to one of the following dietary treatments: $\mathrm{T}_{1}$; basal diet (control), $\mathrm{T}_{2}$; diet supplemented with $0.1 \mathrm{~g} \mathrm{~kg}^{-1}$ of Maxus (antibiotic), $\mathrm{T}_{3}$; diet supplemented with $0.5 \mathrm{~g} \mathrm{~kg}^{-1}$ of Clostat (natural probiotic strain), $\mathrm{T}_{4}$; diet supplemented with $0.12 \mathrm{~g} \mathrm{~kg}^{-1}$ of Sangrovit (phytobiotic), $\mathrm{T}_{5}$; diet supplemented with $0.5 \mathrm{~g} \mathrm{~kg}^{-1}$ of Clostat combined with $0.12 \mathrm{~g} \mathrm{~kg}^{-1}$ of Sangrovit, and $\mathrm{T}_{6}$; diet supplemented with $0.2 \mathrm{~g} \mathrm{~kg}^{-1}$ of Gallipro Tect (spore probiotic). The chicks were fed a starter diet between days 0-14, which was then switched to a grower diet between days 15-35 (Table 1). After $14 \mathrm{~d}$, all treated groups were inoculated with C. perfringens bacteria. Birds were fed ad libitum, and water was available at all times during the experimental period.


a Mokrá Hora, Czechia, as a source of Avilamycin antibiotics (each $1000 \mathrm{~g}$, containing $100 \mathrm{~g}$ of Avilamycin) in feed diets, while, CloStat products were manufactured by KERMIN Ind., Inc., 2100 Maury Street Des Moines, IA 50317 USA (each $1 \mathrm{~g}$, containing $2 \times 10^{7} \mathrm{CFU} / \mathrm{g}$ Bacillus subtilis). The Sangrovit Extra used phytobiotic compounds (extracts of Benzophenanthridine alkaloids (sanguinarine) and protopine) produced by Albitalia s.r.L., Co., Milano, Italy. Gallipro Tect were used as a source of a highly-selected strain (DSM17299) of Bacillus subtilis (B. subtilis $4 \times 10^{9}$ CFU/g DSM 17299), and was provided by Boege Alle Co., Hoersholm, Denmark.

\subsection{Challenge with Clostridium perfringens Bacteria}

The C. perfringens challenge model was performed as described by Prescott [35]. All treated groups received a C. perfringens challenge at a rate of $4 \times 10^{8} \mathrm{CFU} \mathrm{g}^{-1}$ via oral gavages on day 14, as recommended by Olkowski et al. [36], using the defined B positive bacteria C. perfringens isolated from a local farm. The identified bacterium was previously confirmed to be sensitive to antibiotics (Avilamycin) using the broth dilution method (MIC testing) [37]. An inoculum was equipped to contain nearly $10^{8}$ cells of $C$. perfringens per $\mathrm{ml}$ and was processed at a ratio of 1:1.5 ration-to-broth [11]. The challenge feed was mixed with the treatment diet. After the administration of the challenged material, dead birds were counted as study mortalities. These birds underwent a necropsy evaluation to estimate the cause of death/disease. 
Table 1. Composition of starter and finisher diets.

\begin{tabular}{|c|c|c|}
\hline \multirow{2}{*}{ Ingredient } & \multicolumn{2}{|c|}{ Treatment Period (0-35) Days } \\
\hline & Starter (0-15) & Finisher (15-35) \\
\hline Yellow corn & 57.39 & 61.33 \\
\hline Soybean meal & 27.00 & 22.80 \\
\hline Palm oil & 2.20 & 2.80 \\
\hline Corn gluten meal & 8.80 & 6.0 \\
\hline Wheat bran & 0.00 & 3.0 \\
\hline Dicalcium phosphate (DCP) & 2.30 & 2.09 \\
\hline Ground limestone & 0.70 & 0.62 \\
\hline Choline chloride & 0.05 & 0.05 \\
\hline DL-methionine & 0.105 & 0.075 \\
\hline L-lysine & 0.39 & 0.36 \\
\hline Salt & 0.40 & 0.20 \\
\hline Threonine & 0.17 & 0.17 \\
\hline V-M premix ${ }^{1}$ & 0.50 & 0.50 \\
\hline Total & 100 & 100 \\
\hline \multicolumn{3}{|c|}{ Analysis } \\
\hline Metabolizable energy (ME) (kcal/kg) & 3000 & 3050 \\
\hline Crude protein $(\%)$ & 23.0 & 20.5 \\
\hline Non-phytate P (\%) & 0.48 & 0.44 \\
\hline Calcium (\%) & 0.96 & 0.88 \\
\hline Digestible lysine (\%) & 1.28 & 1.15 \\
\hline Digestible methionine (\%) & 0.60 & 0.54 \\
\hline Digestible sulfur amino acids (\%) & 0.95 & 0.86 \\
\hline Digestible threonine $(\%)$ & 0.86 & 0.77 \\
\hline
\end{tabular}

${ }^{1}$ V-M premix; vitamin-mineral premix contains the following per kg: vitamin A, 2,400,000 IU; vitamin D, 1,000,000 $\mathrm{IU}$; vitamin E, 16,000 IU; vitamin K, $800 \mathrm{mg}$; vitamin B1, $600 \mathrm{mg}$; vitamin $\mathrm{B}_{2}, 1600 \mathrm{mg}$; vitamin $\mathrm{B}_{6}, 1000 \mathrm{mg}$; vitamin $\mathrm{B}_{12}, 6 \mathrm{mg}$; niacin, $8000 \mathrm{mg}$; folic acid, $400 \mathrm{mg}$; pantothenic acid, $3000 \mathrm{mg}$; biotin $40 \mathrm{mg}$; antioxidant, $3000 \mathrm{mg}$; cobalt, $80 \mathrm{mg}$; copper, $2000 \mathrm{mg}$; iodine, 400; iron, $1200 \mathrm{mg}$; manganese, 18,000 mg; selenium, $60 \mathrm{mg}$; zinc, 14,000 mg.

\subsection{Growth Performance Parameters}

During the starter (0-14-days-old) and finisher (15-35-days-old) periods, the growth and feed efficiency parameters of the broiler chicks were estimated. The daily feed intake was calculated by subtracting the quantity of feed rejected from the feed offered. Additionally, live body weight was estimated at biweekly intervals, while the final body weight and total feed consumption were determined at the end of each trial period. The body weight gain (BWG) was measured by calculating the difference between the live body weight and final body weight for each trial period. The feed conversion ratio (FCR) was computed for each group, as mentioned by Abudabos et al. [32], using the following formula:

$$
\text { FCR = Feed intake/Weight gain }
$$

Meanwhile, the production efficiency factor (PEF) was calculated as suggested by Griffin [38], using the following formula:

$$
\text { PEF }=(\text { Livability } \times \text { Live weight }(\mathrm{kg})) /(\text { Age in days } \times \text { FCR }) \times 100
$$

During the feeding trial, the number of deaths was counted to calculate the survival rate, as mentioned by Hussein et al. [39], using the following formula:

Survival rate $(\mathrm{SR}) \%=($ the number of the surviving broilers / the initial number of broilers $) \times 100$

\subsection{Carcass Measurements and Lesion Scores}

Ten broiler chicks were randomly collected from each group to estimate the organ weights (heart, gizzard, liver, bursa, spleen, thymus, small and large intestine, and ceca). Chicks were weighed before sacrifice. All internal organs were weighed immediately after slaughter. The gizzard was weighed after its content was removed. The small intestine was measured by determining the distance between 
the site of the duodenum emergence from the gizzard and the beginning of the ceca. The organ weight was calculated relative to the live body weight.

According to the Hofacre et al. [40] procedure, two birds per pen were examined for gross intestinal lesions. The characteristic of necrotic enteritis was defined using the description of the Long et al. [41] study. The lesion scores were outlined as follows: $0=$ none, $1=$ mild, $2=$ moderate and $3=$ marked (severe) [42].

\subsection{Meat Characteristics}

At the end of the finisher period (35-days-old chicks), three birds were randomly selected per pen to estimate the meat characteristics followed by the Chen et al. [43] method. After euthanasia, the jugular vein was cut, the feathers, heads, and shanks were removed, and the remaining carcasses were dissected. The left and right breast from each bird were used for the quality measurements. The breast samples were stored at $-80^{\circ} \mathrm{C}$ until further analysis. At the time of the analysis, frozen muscles were thawed overnight in a chiller at $4{ }^{\circ} \mathrm{C}$.

The $\mathrm{pH}$ of the breast muscle was measured twice (after slaughtering and $24 \mathrm{~h}$ postmortem), using a microprocessor pH-Meter (Model PH 211, Hanna Instruments, Padova, Italy). The core temperature in the breast muscle was measured after slaughtering with a portable digital thermocouple (Eco Scan Series, Temp JKT, Eu tech Instruments, 7 Gul Circle, level 2M, Keppel Logistic Building, Singapore 629563). The colour values of the CIELAB Color System ( $L^{*}$ (lightness), $\mathrm{a}^{*}$ (redness), and b* (yellowness)) were determined for the breast muscles $15 \mathrm{~min}$ and $24 \mathrm{~h}$ after slaughtering, using a Chroma meter (Konica Minolta, CR-400-Japan) following the method used by Castellini et al. [44].

The myofibril fragmentation index (MFI) of the breast muscle was determined by multiplying the absorbance value at $540 \mathrm{~nm}$, as described by Culler et al. [45]. The water-holding capacity (WHC) was determined based on the technique described by Hamm [46] and following the modification performed by Wilhelm et al. [47], using the following equation:

$$
\mathrm{WHC}=100-[(\mathrm{Wi}-\mathrm{Wf} / \mathrm{Wi}) \times 100]
$$

where, Wi and Wf are the initial and final sample weights, respectively.

The drip loss (DL) was determined as a percentage based on the initial sample weight. The cooking loss (CL) was determined as the difference between the initial and final weights. Then, cooked samples were used to evaluate the shear force according to the procedure described by Wheeler et al. [48], under a $200 \mathrm{~mm} / \mathrm{min}$ crosshead speed. The texture profile analysis (TPA) values were estimated using a Texture Analyzer (TA-HD-Stable MicroSystems, Golborne, Warrington WA3 3GR, England) equipped with a compression-platen attachment. The variables determined included the hardness (maximum force needed to compress the sample), cohesiveness (ratio between the total energy required for the first and second compression), springiness (the ability of a sample to recover to its original form after the removal of the compressing force), and chewiness (a resultant of springiness $\times$ hardness $\times$ cohesiveness).

\subsection{Statistical Analysis}

The data underwent a one-way ANOVA using a completely randomized design. Before analysis, the data were examined for normality of distributions and homogeneity of variance. Percentage data were subjected to arcsine transformation before analysis. SPSS 22 analysis software was used for all statistical analyses. Data are expressed as the mean \pm SEM, with a statistical significance level of $p \leq 0.05$. Significant differences between means were determined using Duncan's Multiple Range [49]. 


\section{Results}

\subsection{Growth Performance and Intestinal Lesions Score}

The effects of some feed additives on the total feed intake (TFI), body weight gain (BWG), feed conversion ratio (FCR), and protein efficiency ratio (PEF) of broilers in the starter and finisher periods are shown in Table 2. During the starter period, our results revealed no significant differences between all treatment and non-treatment groups. $\mathrm{T}_{4}$ produced the lowest TFI values, while $\mathrm{T}_{3}$ and $\mathrm{T}_{1}$ exhibited the highest. Regarding the FCR values, both the $\mathrm{T}_{4}$ and $\mathrm{T}_{5}$ treatments had lower values than those of the other treatments. The dietary supplementation of probiotic bacteria increased the PEF (except for $\mathrm{T}_{3}$ ) compared with the control group.

Table 2. Effects of some feed additives on the growth performance, survival rate, and intestinal lesion score of broilers challenged with $C$. perfringens during the starter and finisher feeding periods.

\begin{tabular}{|c|c|c|c|c|c|c|c|c|}
\hline \multirow{2}{*}{ Measurements } & \multicolumn{6}{|c|}{ Treatment } & \multicolumn{2}{|c|}{$p$-Value } \\
\hline & $\mathrm{T}_{1}$ & $\mathrm{~T}_{2}$ & $T_{3}$ & $\mathrm{~T}_{4}$ & $\mathrm{~T}_{5}$ & $\mathrm{~T}_{6}$ & SEM & Sig. \\
\hline \multicolumn{9}{|c|}{ Starter Period (0-14 days-old) } \\
\hline IBW (g) & 36.7 & 36.9 & 36.8 & 36.8 & 36.9 & 36.8 & 0.04 & NS \\
\hline BW $14 \mathrm{~d}(\mathrm{~g})$ & 449 & 443.1 & 448 & 445.5 & 446.6 & 448.1 & 1.089 & NS \\
\hline TFI $(g)$ & 561.1 & 549.9 & 558.6 & 531.1 & 546.8 & 555.0 & 2.049 & NS \\
\hline $\mathrm{BWG}(\mathrm{g})$ & 412.3 & 406.2 & 411.2 & 408.7 & 409.7 & 411.3 & 0.831 & NS \\
\hline FCR (g:g) & 1.36 & 1.35 & 1.36 & 1.30 & 1.33 & 1.35 & 0.05 & NS \\
\hline PEF & 189.0 & 206.4 & 189.2 & 217.0 & 213.8 & 209.0 & 1.049 & NS \\
\hline \multicolumn{9}{|c|}{ Finisher Period (15-35 days-old) } \\
\hline FBW $(g)$ & $1593.3^{b}$ & $1807.4^{\mathrm{a}}$ & $1827.0^{\mathrm{a}}$ & $1824.3^{\mathrm{a}}$ & $1823.1^{a}$ & $1798.9^{a}$ & 1.121 & $* * *$ \\
\hline TFI $(\mathrm{g})$ & 2325.6 & 2366.7 & 2353.2 & 2382.6 & 2379.9 & 2404.4 & 2.865 & NS \\
\hline BWG (g) & $1144.0^{\mathrm{c}}$ & $1364.3^{b}$ & $1379.0^{\mathrm{a}}$ & $1378.8^{\mathrm{a}}$ & $1376.5^{\mathrm{a}}$ & $1350.8^{b}$ & 2.961 & $* * *$ \\
\hline FCR (g:g) & $2.03^{\mathrm{a}}$ & $1.73 \mathrm{bc}$ & $1.71^{\mathrm{c}}$ & $1.73 \mathrm{bc}$ & $1.73 \mathrm{bc}$ & $1.78^{\mathrm{b}}$ & 0.03 & $* * *$ \\
\hline PEF & $215.6^{c}$ & $301.5^{b}$ & $305.0^{\mathrm{ab}}$ & $310.0^{\mathrm{a}}$ & $307.6^{\mathrm{ab}}$ & $288.5^{b}$ & 3.76 & $* * *$ \\
\hline SR $(\%)$ & $97.2^{\mathrm{b}}$ & $99.8^{\mathrm{a}}$ & $99.6^{a}$ & $99.8^{\mathrm{a}}$ & $99.8^{a}$ & $99.6^{a}$ & 0.30 & $* * *$ \\
\hline Lesions score & $2.50^{\mathrm{a}}$ & $0.67^{\mathrm{b}}$ & $0.66^{\mathrm{b}}$ & $0.67^{b}$ & $0.33^{c}$ & $0.50^{\mathrm{b}}$ & 0.26 & $* * *$ \\
\hline
\end{tabular}

IBW, initial body weight; BW $14 \mathrm{~d}$, body weight at 14 days of age; FBW, final body weight; TFI, total feed intake; BWG, bodyweight gain; FCR, feed conversion ratio; PEF, protein efficiency ratio; and SR, survival rate. SEM, mean values of the standard error. Mean values of three replicates with deferent letters $(a, b, c)$ in the same row are significantly different $(p<0.05)$. Sig, significance; NS, non-significance; ${ }^{* * *}$ significance at $p<0.001$.

During the finisher period, all experimental additives significantly increased $(p<0.01)$ the FBW, BWG, FCR, PEF, survival rate (SR), and decreased the intestinal lesions score compared with those of the control group (Table 2). However, the TFI was not significantly affected by the supplemented diets. The $\mathrm{T}_{3}, \mathrm{~T}_{4}$ and $\mathrm{T}_{5}$ groups had higher BWG values compared with those of the other groups. Additionally, the $\mathrm{T}_{3}$-treated group exhibited the best FCR values, while the different treatment groups produced intermediate FCR values. Regarding the PEF values, compared with the control, all experimental additives were significantly enhanced $(p<0.05)$. The SR $(\%)$ and lesions score were enhanced considerably by the dietary treatments at 15-35 days of age (Table 2 ).

\subsection{Carcass Measurements}

The effects of supplemented diets on carcass traits after a 35-day feeding trial are presented in Table 3. Regarding the $\mathrm{T}_{6}$ treatment group, the dressing percentage showed significant $(p<0.05)$ increases. Also, the $\mathrm{T}_{1}$ and $\mathrm{T}_{3}$ treatment groups recorded the highest significant thymus values, while the lowest values were recorded for $\mathrm{T}_{4}$. Meanwhile, the highest significant $(p<0.05)$ spleen weight percentage value was recorded in the $T_{5}$ group. 
Table 3. Effects of some feed additives on the carcass traits of broilers challenged with C. perfringens during the starter and finisher feeding periods.

\begin{tabular}{|c|c|c|c|c|c|c|c|c|}
\hline \multirow{2}{*}{ Measurements } & \multicolumn{6}{|c|}{ Treatment } & \multicolumn{2}{|c|}{$p$-Value } \\
\hline & $T_{1}$ & $\mathbf{T}_{2}$ & $\mathbf{T}_{3}$ & $\mathbf{T}_{4}$ & $T_{5}$ & $T_{6}$ & SEM & Sig. \\
\hline $\mathrm{DP}(\%)^{10}$ & $65.7^{b}$ & $67.4^{b}$ & $67.3^{b}$ & $67.5^{b}$ & $67.4^{b}$ & $68.3^{a}$ & 0.65 & $* *$ \\
\hline Breast $(\%)^{10}$ & 24.8 & 25.6 & 24.9 & 26.2 & 25.6 & 25.8 & 0.94 & NS \\
\hline $\operatorname{Leg}(\%)^{10}$ & 19.4 & 19.5 & 19.5 & 18.6 & 19.5 & 19.4 & 0.67 & NS \\
\hline Fat $(\%)^{10}$ & 1.35 & 1.25 & 1.37 & 1.08 & 1.30 & 1.45 & 0.18 & NS \\
\hline Liver $(\%)^{10}$ & 2.58 & 2.48 & 2.47 & 2.82 & 2.43 & 2.23 & 0.14 & NS \\
\hline Bursa $(\%)^{10}$ & 0.17 & 0.19 & 0.16 & 0.15 & 0.20 & 0.19 & 0.02 & NS \\
\hline Spleen $(\%)^{10}$ & $0.11^{\mathrm{ab}}$ & $0.11^{\mathrm{ab}}$ & $0.09^{b}$ & $0.12^{a b}$ & $0.13^{\mathrm{a}}$ & $0.10^{b}$ & 0.09 & $* *$ \\
\hline Thymus $(\%)^{10}$ & $0.52^{\mathrm{a}}$ & $0.49^{a b}$ & $0.57^{\mathrm{a}}$ & $0.42^{\mathrm{c}}$ & $0.49^{a b}$ & $0.45^{b}$ & 0.04 & $*$ \\
\hline Gizzard (\%) $)^{10}$ & 3.52 & 2.85 & 2.90 & 3.08 & 3.38 & 3.10 & 0.21 & NS \\
\hline Heart $(\%)^{10}$ & 0.53 & 0.45 & 0.48 & 0.60 & 0.57 & 0.50 & 0.04 & NS \\
\hline
\end{tabular}

$\mathrm{DP}$, dressing percentage. SEM, mean values of the standard error. Mean values of three replicates with different letters $\left({ }^{a}, b, c\right)$ in the same row are significantly different $(p<0.05)$. Sig, significance; NS, non-significance; *, significance at $p<0.05 ; * *$, significance at $p<0.01$.

\subsection{Meat Characteristics}

The effects of feed additives on broiler meat quality parameters are presented in Table $4 . T_{3} T_{3}$ and $\mathrm{T}_{5}$ treatments resulted in the lowest $\mathrm{pHi}$ values, with the highest values observed in $\mathrm{T}_{2}$. Conversely, the $\mathrm{pHu}$ was significantly reduced by the treatments, with the lowest values recorded in $\mathrm{T}_{5}$ and $\mathrm{T}_{6}$. Furthermore, the Temperature was significantly reduced in $\mathrm{T}_{6}$ followed by $\mathrm{T}_{5}$-treated groups compared with other treated groups. However, no significant differences were demonstrated among the other treatment groups concerning the colour component after slaughter (L15 and b15) and $24 \mathrm{~h}$ (L24, a24, and b24) at 35 days of age.

Table 4. Effects of some feed additives on the meat quality of broilers challenged with C. perfringens during a feeding trial period.

\begin{tabular}{|c|c|c|c|c|c|c|c|c|}
\hline \multirow{2}{*}{ Measurements } & \multicolumn{6}{|c|}{ Treatment } & \multicolumn{2}{|c|}{$p$-Value } \\
\hline & $\mathbf{T}_{1}$ & $\mathbf{T}_{2}$ & $\mathbf{T}_{3}$ & $\mathbf{T}_{4}$ & $\mathbf{T}_{5}$ & $\mathrm{~T}_{6}$ & SEM & Sig. \\
\hline $\mathrm{pHi}$ & $6.58^{\mathrm{ab}}$ & $6.63^{a}$ & $6.52^{b}$ & $6.59 \mathrm{ab}$ & $6.55^{b}$ & $6.60^{a b}$ & 0.03 & $* *$ \\
\hline $\mathrm{pHu}$ & $6.00^{b}$ & $6.07^{\mathrm{a}}$ & $6.05^{\mathrm{ab}}$ & $6.05^{a b}$ & $5.93^{c}$ & $5.94^{\mathrm{c}}$ & 0.02 & $* * *$ \\
\hline Temperature $\left({ }^{\circ} \mathrm{C}\right)$ & $\begin{array}{c}27.82 \\
\mathrm{ab}\end{array}$ & $28.43^{a}$ & $28.98^{a}$ & $\begin{array}{c}27.03 \\
\mathrm{ab}\end{array}$ & $26.10^{b}$ & $24.84^{c}$ & 0.32 & $* * *$ \\
\hline $\mathrm{L}^{*} 15$ & 42.29 & 45.22 & 45.56 & 44.11 & 44.40 & 44.38 & 0.93 & NS \\
\hline$a^{*} 15$ & 6.32 & 4.78 & 6.09 & 7.26 & 5.37 & 4.97 & 0.64 & NS \\
\hline $\mathrm{b}^{*} 15$ & 2.34 & 2.68 & 2.68 & 1.91 & 2.23 & 1.73 & 0.55 & NS \\
\hline $\mathrm{L}_{24}^{*}$ & 52.69 & 52.70 & 52.63 & 53.35 & 53.84 & 53.60 & 0.81 & NS \\
\hline$a^{*} 24$ & 5.11 & 5.85 & 5.57 & 6.75 & 5.51 & 5.76 & 0.60 & NS \\
\hline $\mathrm{b}_{24}^{*}$ & 6.57 & 5.77 & 5.58 & 5.52 & 7.50 & 6.50 & 0.71 & NS \\
\hline
\end{tabular}

$\mathrm{pHi}$, meat $\mathrm{pH}$ after slaughter; $\mathrm{pHu}$, meat $\mathrm{pH}$ after $24 \mathrm{~h}$; Temp., carcass temperature after slaughter; L15, a15, and b15, colour components after slaughter; and $L^{*} 24, a^{*} 24$, and $b^{*} 24$, colour components after $24 \mathrm{~h}$. SEM, mean values of the standard error. Mean values of three replicates with different letters $\left({ }^{\mathrm{a}, \mathrm{b}, \mathrm{c}}\right)$ in the same row are significantly different $(p<0.05)$. Sig, significance; NS, non-significance; ${ }^{* *}$, significance at $p<0.01 ;{ }^{* * *}$, significance at $p<0.001$.

The results presented in Table 5 reveal the effects of feed additives on meat characteristics, such as the Cooking Loss (CL), Water Holding Capacity (WHC), Myofiber Fragmentation Index (MFI), Shear Force (SF) and texture profile analysis (TPA) at 35 days of age under a C. perfringens challenge test. All treatment groups showed no significant differences concerning the CL, WHC, MFI, and SF. The $\mathrm{T}_{6}$ and $\mathrm{T}_{5}$ treatments exhibited significantly increased $(p<0.001)$ hardness and chewiness values compared with those of other treatment groups, respectively. Although the dietary supplementation showed no significant differences in Springiness and Cohesiveness values between all treated groups. 
Table 5. Effects of some feed additives on the meat characteristics of broilers challenged with $C$. perfringens during a feeding trial period.

\begin{tabular}{ccccccccc}
\hline \multirow{2}{*}{ Measurements } & \multicolumn{9}{c}{ Treatment } & \multicolumn{3}{c}{$p$-Value } \\
\cline { 2 - 9 } & $\mathbf{T}_{\mathbf{1}}$ & $\mathbf{T}_{\mathbf{2}}$ & $\mathbf{T}_{\mathbf{3}}$ & $\mathbf{T}_{\mathbf{4}}$ & $\mathbf{T}_{\mathbf{5}}$ & $\mathbf{T}_{\mathbf{6}}$ & $\mathbf{S E M}$ & Sig. \\
\hline CL\% & 25.98 & 26.85 & 30.56 & 29.65 & 29.38 & 28.87 & 1.61 & NS \\
WHC & 0.25 & 0.31 & 0.28 & 0.29 & 0.28 & 0.28 & 0.02 & NS \\
MFI & 108.43 & 90.70 & 91.27 & 110.55 & 109.12 & 110.67 & 5.14 & NS \\
SF (kg) & 1.26 & 1.54 & 1.44 & 1.44 & 1.40 & 1.40 & 0.18 & NS \\
\hline Hardness (kg) & $1.09^{\mathrm{b}}$ & $0.69^{\mathrm{c}}$ & $0.71^{\mathrm{bc}}$ & $1.21^{\mathrm{ab}}$ & $1.49^{\mathrm{a}}$ & $1.51^{\mathrm{a}}$ & 0.12 & $* * *$ \\
Springiness & 0.58 & 0.61 & 0.62 & 0.59 & 0.58 & 0.60 & 0.02 & $\mathrm{NS}$ \\
Cohesiveness & 0.53 & 0.51 & 0.53 & 0.52 & 0.50 & 0.52 & 0.01 & NS \\
Chewiness & $0.34^{\mathrm{b}}$ & $0.22^{\mathrm{c}}$ & $0.24^{\mathrm{c}}$ & $0.37^{\mathrm{ab}}$ & $0.43^{\mathrm{a}}$ & $0.47^{\mathrm{a}}$ & 0.04 & $* * *$ \\
\hline
\end{tabular}

CL, cooking loss; WHC, water holding capacity; MFI, Myofiber Fragmentation Index; SF, shear force; and TPA, texture profile analysis. SEM, mean values of the standard error. Mean values of three replicates with different letters $(\mathrm{a}, \mathrm{b}, \mathrm{c})$ in the same row are significantly different $(p<0.05)$. Sig, significance; NS, non-significance; ${ }^{* * *}$, significance at $p<0.001$.

\section{Discussion}

Necrotic enteritis (NE) has become one of the most critical problems in the poultry industry [50]. Feed additives, including antibiotics, prebiotics, and probiotics, have frequently been used for improving the health, growth, and feed efficiency parameters of animals [51]. Recently, interest in incorporating probiotics and antibiotics into broiler treatments has been rapidly increasing [52]. Several studies have shown that the addition of probiotics has positive effects on the growth rate, feed utilization, feed efficiency, and mortality rate $[53,54]$. However, the efficacy of probiotics depends upon the selection of more efficient strains, manipulation of genes, a combination of several strains, and the combination of probiotics and synergistically=acting components [55]. The use of multi-strain probiotics seems to be the best way of potentiating the efficacy of probiotics, as it beneficially affects the host by improving growth-promoting bacteria with competitive antagonism against pathogenic bacteria in the gastrointestinal tract [56].

\subsection{Growth Performance}

The performance results obtained in the starter period and the finisher period are presented in Table 2. The IBW, TFI, BWG, and FCR of all groups receiving feed-supplemented diets and basal diets had no significant differences among them. However, the BWG, FBW, PEF, FCR, and SR during the finisher phase, at 15-35 days-old, were significantly $(p<0.05)$ improved in all supplemented diets compared to the control group. These results are similar to those of Khaksefidi and Ghoorchi [57], who found that the BWG of birds fed a diet supplemented with $50 \mathrm{mg} / \mathrm{kg}$ of Bacillus subtilis was significantly higher during the finisher period (22-42 d) than birds fed the control diets. Additionally, the feed conversion ratio of birds fed a diet supplemented with probiotics significantly reduced from 22 to $42 \mathrm{~d}$ compared with birds fed the control diets. Consequently, Patel et al. [55] indicated that the dietary supplementation of combined probiotics and prebiotics (Protexin) at $100 \mathrm{~g} /$ ton of feed significantly enhanced the BWG, along with an improved FCR, and benefitted without any adverse effects on the feed intake, mortality, or carcass characteristics. Also, Anjum et al. [58] and Singh et al. [59] observed similar results. The improvement of all performance parameters may be due to the biological role of probiotics in altering the intestinal $\mathrm{pH}$, which modifies both the microbial population and nutrient absorption, ultimately improving the efficiency of feed utilization [60]. Moreover, increased feed intake and digestive enzyme secretions also are detected in animals' fortified phytobiotic-supplemented feed [61]. Growth enhancement through the use of phytobiotics probably depends on the synergistic effects among complex active molecules present in phytobiotics [39,62]. 
The mortality rate in this study was low (finisher period), representing the positive effect of feed additives on the mortality rate (Table 2). These findings were similar to those found by Abdel-Hafeez et al. [63] and Riad et al. [64], who indicated that the addition of probiotics as feed additives decreased the mortality rate. The reduction in mortality was attributed to the inhibitory effects of these additives toward enteric microorganisms via modifying the intestinal $\mathrm{pH}$ [63]. Compared to a wide range of antibiotics (including Avilamycin), a significant decrease in mortality was seen for treated broilers with $2 \mathrm{~g} / \mathrm{kg}$ Bio-Mannan-oligosaccharides (Bio-MOS) as a source of prebiotic, depending on the age of birds $[65,66]$. Moreover, there are major modes of action by which broiler performance is improved by proposed oligosaccharide prebiotics, such as control of type-1fimbriae pathogenic bacteria (mannose-sensitive lectin), immune modulation effects, and modulation of intestinal morphology and expression of mucin and brush border enzymes [67].

\subsection{Carcass Traits}

The mean values for the carcass characteristics, dressing percentage, and organ weight (\%) relative to the bodyweight of the broilers are presented in Table 3. The dressing percentage was significantly $(p<0.05)$ increased in the $\mathrm{T}_{6}$ group compared with those of the other treatments. However, non-significant differences were observed in the other carcass measurements amongst the treatment groups. Some organ weight (spleen and thymus) significantly increased in probiotic supplemented diets alone or in combination with prebiotics compared with other treated groups. Generally, the inclusion of probiotics in broiler rations had no extra additional benefits for the organ weight or carcass yield [55]. Also, Salamkhan et al. [68], Panda et al. [69], and Patel et al. [55] reported that the dressing percentage did not differ significantly $(p \leq 0.05)$ between the probiotics-fed broilers and control broilers. To contrast, Banday and Risam [70] and Kabir et al. [71] observed a significant $(p \leq 0.05)$ improvement in the dressing percentage in groups supplemented with probiotics. Nevertheless, Sarangi et al. [72] reported a highly significant increment in breast yield in birds supplemented with prebiotics. Jin et al. [73] attributed the lower fat deposition in birds treated with probiotics to how the product could interfere in the availability of fat for lipogenesis in the birds.

\subsection{Meat Quality Parameters}

The effects of antibiotic-, probiotic-, and phytobiotic-supplemented diets on the measurements of meat characteristics under C. perfringens infection in broilers are presented in Table 4 . The change in $\mathrm{pH}$ is one of the most significant changes that can occur during rigor mortis and can affect meat quality characteristics, such as texture, colour, and WHC [74]. Fletcher et al. [75] reported that post-mortem $\mathrm{pH}$ measurements are a good indicator of meat characteristics. Generally, a rapid post-mortem $\mathrm{pH}$ decline in breast meat can lead to protein denaturation, which may result in a pale colour and low WHC [76]. During this trial, the temperature and $\mathrm{pH}$ values obtained after slaughter and $24 \mathrm{~h}$ post-slaughter showed significant $(p \leq 0.05)$ enhancements for all supplemented diets compared with the group fed the basal diet. These results are similar to those found by Battula et al. [77] and Corzo et al. [78] where the bacterial challenge had negative impacts on the temperature and $\mathrm{pH}$ of the breast muscle.

Additionally, the cooking loses (CL) is a measure of the percentage of water lost during cooking as a result of shrinkage. Consequently, the degree of shrinkage upon cooking is directly correlated with a loss of juiciness. During this trial, the CL, WHC, and SF showed non-significant differences between the control and treatment groups. During a subsequent study, Pelicano et al. [79] examined the effects of Lactobacillus- and Bacillus subtilis-based probiotics on SF and reported non-significant values compared with the control group. However, the MFI of the breast muscle was influenced by the treatments $(p \leq 0.05)$, as shown in Table 4. The MFI decreased in $\mathrm{T}_{2}$ and $\mathrm{T}_{3}$ compared with the other treatment groups. Myofibrillar fragmentation is the extent of myofibril destruction caused by homogenization [80]. Olson and Stromer [81] reported that MFI values are correlated with other muscle indices, such as SF and tenderness. Therefore, it can be concluded that probiotic supplementation causes less damage to the myofibrils [76]. 
TPA is an instrumental measurement of the sensory attributes of chicken breasts which imitates the conditions to which food is subjected to in the mouth [76]. The TPA, which includes hardness, cohesiveness, springiness, and chewiness, is shown in Table 5. The treatments had no significant effects on any TPA variable $(p \leq 0.05)$. All tested groups were very tender, except for the $\mathrm{T}_{6}$ and $\mathrm{T}_{5}$ supplemented groups, which had hardness values that were significantly $(p \leq 0.001)$ higher than those of the other treatment groups. The data presented in this trial aligns with that of Angelovicova et al. [82] who noticed that probiotics (CloStat) moderately affect the hardness, cohesiveness, springiness, and chewiness of cooked breast meat. Also, Lisowski et al. [83] investigated a beneficial effect of the prebiotic on breast muscle weight and carcass percentage. It could be supposed on the one hand, that using prebiotics in broiler diets has a positive influence on muscle weight [84].

\section{Conclusions}

To conclude, fortified feed diets with $0.2,0.5,0.12 \mathrm{~g} \mathrm{~kg}^{-1}$ of Bacillus subtilis spores (Gallipro Tect), live Bacillus strain (CloStat) and phytobiotic natural compounds (Sangrovit Extra) respectively, alone or in combined form, could promote growth and reduce the NE mortality rates. Additionally, using these probiotic and phytobiotic compounds as an alternative for antibiotics in feed diets could be a useful strategy to ameliorate the harmful effects of $C$. perfringens bacterium on broilers, in terms of the performance, feed efficiency, meat quality and carcass characteristics regarding necrotic enteritis infections.

Author Contributions: Conceptualization, E.O.S.H. and S.H.A.; methodology, A.M.A. and G.M.S.; software, E.O.S.H., A.M.A. and G.M.S.; investigation, M.E.A.E.-H.; data curation, M.E.A.E-H. and A.A.S.; writing-original draft preparation, review and editing; A.N.A., visualization. All authors have read and agreed to the published version of the manuscript.

Funding: Authors would like to extend their sincere appreciation to the Deanship of Scientific Research at King Saud University for its funding of this research through Research Group Project No. RGP-267.

Conflicts of Interest: Authors declare no conflict of interest.

\section{References}

1. Abudabos, A.M.; Ali, M.H.; Nassan, M.A.; Saleh, A.A. Ameliorative Effect of Bacillus subtilis on Growth Performance and Intestinal Architecture in Broiler Infected with Salmonella. Animals 2019, 9, 190. [CrossRef] [PubMed]

2. Niilo, L. Enterotoxemic Clostridium perfringens. In Pathogenesis of Bacterial Infections in Animals; Wiley-Blackwell: Tucson, AZ, USA, 1993; pp. 114-123.

3. Hatheway, C.L. Toxigenic clostridia. Clin. Microbiol. Rev. 1990, 3, 66-98. [CrossRef] [PubMed]

4. Cooper, K.; Trinh, H.; Songer, J.G. Immunization with recombinant alpha toxin partially protects broiler chicks against experimental challenge with Clostridium perfringens. Vet. Microbiol. 2009, 133, 92-97. [CrossRef] [PubMed]

5. Van Immerseel, F.; Rood, J.I.; Moore, R.J.; Titball, R.W. Rethinking our understanding of the pathogenesis of necrotic enteritis in chickens. Trends Microbiol. 2009, 17, 32-36. [CrossRef]

6. Miyamoto, K.; Fisher, D.J.; Li, J.; Sayeed, S.; Akimoto, S.; McClane, B.A. Complete sequencing and diversity analysis of the enterotoxin-encoding plasmids in Clostridium perfringens type A non-food-borne human gastrointestinal disease isolates. J. Bacteriol. 2006, 188, 1585-1598. [CrossRef]

7. Morris, W.; Fernández-Miyakawa, M. Toxinas de Clostridium perfringens. Rev. Argent. Microbiol. 2009, 41, 251-260.

8. Osman, K.; Soliman, Y.; Amin, Z.; Aly, M. Prevalence of Clostridium perfringens type A isolates in commercial broiler chickens and parent broiler breeder hens in Egypt. Rev. Sci. Tech. Off. Int. Epiz 2012, 31, 931-941. [CrossRef]

9. Paiva, D.; McElroy, A. Necrotic enteritis: Applications for the poultry industry. J. Appl. Poult. Res. 2014, 23, 557-566. [CrossRef]

10. Fenichel, G.M. Clinical Pediatric Neurology: A Signs and Symptoms Approach; Elsevier Health Sciences: Amsterdam, The Netherlands, 2009. 
11. Paradis, M.A.; McMillan, E.; Bagg, R.; Vessie, G.; Zocche, A.; Thompson, M. Efficacy of avilamycin for the prevention of necrotic enteritis caused by a pathogenic strain of Clostridium perfringens in broiler chickens. Avian Pathol. 2016, 45, 365-369. [CrossRef]

12. Brennan, J.; Bagg, R.; Barnum, D.; Wilson, J.; Dick, P. Efficacy of narasin in the prevention of necrotic enteritis in broiler chickens. Avian Dis. 2001, 45, 210-214. [CrossRef]

13. Butaye, P.; Devriese, L.A.; Haesebrouck, F. Antimicrobial growth promoters used in animal feed: Effects of less well known antibiotics on gram-positive bacteria. Clin. Microbiol. Rev. 2003, 16, 175-188. [CrossRef] [PubMed]

14. Mwangi, S.; Timmons, J.; Fitz-Coy, S.; Parveen, S. Characterization of Clostridium perfringens recovered from broiler chicken affected by necrotic enteritis. Poult. Sci. 2018, 98, 128-135. [CrossRef] [PubMed]

15. Fooks, L.J.; Fuller, R.; Gibson, G.R. Prebiotics, probiotics and human gut microbiology. Int. Dairy J. 1999, 9, 53-61. [CrossRef]

16. Arif, M.; Iram, A.; Bhutta, M.A.; Naiel, M.A.; Abd El-Hack, M.E.; Othman, S.I.; Allam, A.A.; Amer, M.S.; Taha, A.E. The Biodegradation Role of Saccharomyces cerevisiae against Harmful Effects of Mycotoxin Contaminated Diets on Broiler Performance, Immunity Status, and Carcass characteristics. Animals 2020, 10, 238. [CrossRef]

17. El-Shall, N.A.; Awad, A.M.; Abd El-Hack, M.E.; Naiel, M.A.; Othman, S.I.; Allam, A.A.; Sedeik, M.E. The Simultaneous Administration of a Probiotic or Prebiotic with Live Salmonella Vaccine Improves Growth Performance and Reduces Fecal Shedding of the Bacterium in Salmonella-Challenged Broilers. Animals 2020, 10, 70. [CrossRef]

18. Caly, D.L.; D'Inca, R.; Auclair, E.; Drider, D. Alternatives to antibiotics to prevent necrotic enteritis in broiler chickens: A microbiologist's perspective. Front. Microbiol. 2015, 6, 1336. [CrossRef]

19. Joerger, R. Alternatives to antibiotics: Bacteriocins, antimicrobial peptides and bacteriophages. Poult. Sci. 2003, 82, 640-647. [CrossRef]

20. Pan, D.; Yu, Z. Intestinal microbiome of poultry and its interaction with host and diet. Gut Microbes 2014, 5, 108-119. [CrossRef]

21. Sassone-Corsi, M.; Raffatellu, M. No vacancy: How beneficial microbes cooperate with immunity to provide colonization resistance to pathogens. J. Immunol. 2015, 194, 4081-4087. [CrossRef]

22. Barbosa, T.M.; Serra, C.R.; La Ragione, R.M.; Woodward, M.J.; Henriques, A.O. Screening for Bacillus isolates in the broiler gastrointestinal tract. Appl. Environ. Microbiol. 2005, 71, 968-978. [CrossRef]

23. Gérard, P.; Brézillon, C.; Quéré, F.; Salmon, A.; Rabot, S. Characterization of cecal microbiota and response to an orally administered lactobacillus probiotic strain in the broiler chicken. J. Mol. Microbiol. Biotechnol. 2008, 14, 115-122. [CrossRef] [PubMed]

24. Knap, I.; Lund, B.; Kehlet, A.; Hofacre, C.; Mathis, G. Bacillus licheniformis prevents necrotic enteritis in broiler chickens. Avian Dis. 2010, 54, 931-935. [CrossRef] [PubMed]

25. La Ragione, R.M.; Woodward, M.J. Competitive exclusion by Bacillus subtilis spores of Salmonella enterica serotype Enteritidis and Clostridium perfringens in young chickens. Vet. Microbiol. 2003, 94, 245-256. [CrossRef]

26. Sokale, A.; Menconi, A.; Mathis, G.; Lumpkins, B.; Sims, M.; Whelan, R.; Doranalli, K. Effect of Bacillus subtilis DSM 32315 on the intestinal structural integrity and growth performance of broiler chickens under necrotic enteritis challenge. Poult. Sci. 2019, 98, 5392-5400. [CrossRef] [PubMed]

27. Jayaraman, S.; Thangavel, G.; Kurian, H.; Mani, R.; Mukkalil, R.; Chirakkal, H. Bacillus subtilis PB6 improves intestinal health of broiler chickens challenged with Clostridium perfringens-induced necrotic enteritis. Poult. Sci. 2013, 92, 370-374. [CrossRef] [PubMed]

28. Naiel, M.A.; Ismael, N.E.; Shehata, S.A. Ameliorative effect of diets supplemented with rosemary (Rosmarinus officinalis) on aflatoxin B1 toxicity in terms of the performance, liver histopathology, immunity and antioxidant activity of Nile Tilapia (Oreochromis niloticus). Aquaculture 2019, 511, 734264. [CrossRef]

29. Alagawany, M.; Abd El-Hack, M.E.; Al-Sagheer, A.A.; Naiel, M.A.; Saadeldin, I.M.; Swelum, A.A. Dietary cold pressed watercress and coconut oil mixture enhances growth performance, intestinal microbiota, antioxidant status, and immunity of growing rabbits. Animals 2018, 8, 212. [CrossRef]

30. Al-Sagheer, A.A.; Abd El-Hack, M.E.; Alagawany, M.; Naiel, M.A.; Mahgoub, S.A.; Badr, M.M.; Hussein, E.O.; Alowaimer, A.N.; Swelum, A.A. Paulownia leaves as a new feed resource: Chemical composition and effects on growth, carcasses, digestibility, blood biochemistry, and intestinal bacterial populations of growing rabbits. Animals 2019, 9, 95. [CrossRef] 
31. Vidanarachchi, J.K.; Mikkelsen, L.; Sims, I.; Iji, P.; Choct, M. Phytobiotics: Alternatives to antibiotic growth promoters in monogastric animal feeds. Recent Adv. Anim. Nutr. Aust. 2005, 15, 131-144.

32. Abudabos, A.M.; Alyemni, A.H.; Dafalla, Y.M.; Khan, R.U. The effect of phytogenics on growth traits, blood biochemical and intestinal histology in broiler chickens exposed to Clostridium perfringens challenge. J. Appl. Anim. Res. 2018, 46, 691-695. [CrossRef]

33. El-Sheikh, S.M.; Khairy, M.H.; Eleiwa, N.Z.; Abdalla, O.E.; El-Monsef, A.G.A. Effect of sanguinarine phytobiotic, sodium butyrate compared to ampicillin on controlling necrotic enteritis in broiler chickens. In Proceedings of the Veterinary Medicine In-between Health \& Economy (VMHE), Cairo, Egypt, 16-19 October 2018; Volume 55.

34. Clavijo, V.; Flórez, M.J.V. The gastrointestinal microbiome and its association with the control of pathogens in broiler chicken production: A review. Poult. Sci. 2018, 97, 1006-1021. [CrossRef] [PubMed]

35. Prescott, J. The prevention of experimentally induced necrotic enteritis in chickens by avoparcin. Avian Dis. 1979, 23, 1072-1074. [CrossRef] [PubMed]

36. Olkowski, A.; Wojnarowicz, C.; Chirino-Trejo, M.; Drew, M. Responses of broiler chickens orally challenged with Clostridium perfringens isolated from field cases of necrotic enteritis. Res. Vet. Sci. 2006, 81, 99-108. [CrossRef] [PubMed]

37. Nakamura, C.V.; Ueda-Nakamura, T.; Bando, E.; Melo, A.F.N.; Cortez, D.A.G.; Dias Filho, B.P. Antibacterial activity of Ocimum gratissimum L. essential oil. Memórias Inst. Oswaldo Cruz 1999, 94, 675-678. [CrossRef] [PubMed]

38. Griffin, R. The response of cage-reared broiler cockerels to dietary supplements of nitrovin, zinc bacitracin or penicillin used singly or in paired combinations. Br. Poult. Sci. 1979, 20, 281-287. [CrossRef]

39. Hussein, E.O.S.; Ahmed, S.H.; Abudabos, A.M.; Aljumaah, M.R.; Alkhlulaifi, M.M.; Nassan, M.A.; Suliman, G.M.; Naiel, M.A.E.; Swelum, A.A. Effect of Antibiotic, Phytobiotic and Probiotic Supplementation on Growth, Blood Indices and Intestine Health in Broiler Chicks Challenged with Clostridium perfringens. Animals 2020, 10, 507. [CrossRef]

40. Hofacre, C.; Beacorn, T.; Collett, S.; Mathis, G. Using competitive exclusion, mannan-oligosaccharide and other intestinal products to control necrotic enteritis. J. Appl. Poult. Res. 2003, 12, 60-64. [CrossRef]

41. Long, J.; Barnum, D.; Pettit, J. Necrotic enteritis in broiler chickens II. Pathology and proposed pathogenesis. Can. J. Comp. Med. 1974, 38, 467.

42. Hofacre, C.; Froyman, R.; Gautrias, B.; George, B.; Goodwin, M.; Brown, J. Use of Aviguard and other intestinal bioproducts in experimental Clostridium perfringens-associated necrotizing enteritis in broiler chickens. Avian Dis. 1998, 42, 579-584. [CrossRef]

43. Chen, X.; Jiang, W.; Tan, H.; Xu, G.; Zhang, X.; Wei, S.; Wang, X. Effects of outdoor access on growth performance, carcass composition, and meat characteristics of broiler chickens. Poult. Sci. 2013, 92, 435-443. [CrossRef]

44. Castellini, C.; Mugnai, C.; Dal Bosco, A. Effect of organic production system on broiler carcass and meat quality. Meat Sci. 2002, 60, 219-225. [CrossRef]

45. Culler, R.; Smith, G.; Cross, H. Relationship of myofibril fragmentation index to certain chemical, physical and sensory characteristics of bovine longissimus muscle. J. Food Sci. 1978, 43, 1177-1180. [CrossRef]

46. Hamm, R. Biochemistry of meat hydration. In Advances in Food and Nutrition Research; Elsevier: Amsterdam, the Netherlands, 1961; Volume 10, pp. 355-463.

47. Wilhelm, A.E.; Maganhini, M.B.; Hernández-Blazquez, F.J.; Ida, E.I.; Shimokomaki, M. Protease activity and the ultrastructure of broiler chicken PSE (pale, soft, exudative) meat. Food Chem. 2010, 119, 1201-1204. [CrossRef]

48. Wheeler, T.; Cundiff, L.; Shackelford, S.; Koohmaraie, M. Characterization of biological types of cattle (Cycle VII): Carcass, yield, and longissimus palatability traits. J. Anim. Sci. 2005, 83, 196-207. [CrossRef]

49. Duncan, D.B. Multiple range and multiple F tests. Biometrics 1955, 11, 1-42. [CrossRef]

50. Wang, H.; Ni, X.; Qing, X.; Liu, L.; Lai, J.; Khalique, A.; Li, G.; Pan, K.; Jing, B.; Zeng, D. Probiotic enhanced intestinal immunity in broilers against subclinical necrotic enteritis. Front. Immunol. 2017, 8, 1592. [CrossRef]

51. Kefali, S.; Kaygisiz, F.; Toker, N. Effect of probiotics on feed consumption, live weight gain and production cost in broilers. Indian Vet. J. 2007, 84, 267-269.

52. De Jesus, R.; Waitzberg, D.; Campos, F. More Channels Showcase Channel Catalog. Rev. Assoc. Med. Bras. 2000, 46. [CrossRef] 
53. El-Naga, M. Effect of dietary yeast supplementation on broiler performance. Egyp. Poult. Sci. J. 2012, 32, 95-106.

54. Sen, S.; Ingale, S.; Kim, Y.; Kim, J.; Kim, K.; Lohakare, J.; Kim, E.; Kim, H.; Ryu, M.; Kwon, I. Effect of supplementation of Bacillus subtilis LS 1-2 to broiler diets on growth performance, nutrient retention, caecal microbiology and small intestinal morphology. Res. Vet. Sci. 2012, 93, 264-268. [CrossRef]

55. Patel, S.G.; Raval, A.P.; Bhagwat, S.R.; Sadrasaniya, D.A.; Patel, A.P.; Joshi, S.S. Effects of probiotics supplementation on growth performance, feed conversion ratio and economics of broilers. J. Anim. Res. 2015, 5, 155. [CrossRef]

56. Lukic, J.; Chen, V.; Strahinic, I.; Begovic, J.; Lev-Tov, H.; Davis, S.C.; Tomic-Canic, M.; Pastar, I. Probiotics or pro-healers: The role of beneficial bacteria in tissue repair. Wound Repair Regen. 2017, 25, 912-922. [CrossRef] [PubMed]

57. Khaksefidi, A.; Ghoorchi, T. Effect of probiotic on performance and immunocompetence in broiler chicks. J. Poult. Sci. 2006, 43, 296-300. [CrossRef]

58. Anjum, M.; Khan, A.; Azim, A.; Afzal, M. Effect of dietary supplementation of multi-strain probiotic on broiler growth performance. Pak. Vet. J. 2005, 25, 25-29.

59. Singh, S.; Niranjan, P.; Singh, U.; Koley, S.; Verma, D. Effects of dietary supplementation of probiotics on broiler chicken. Anim. Nutr. Feed Technol. 2009, 9, 85-90.

60. Dunne, C. Adaptation of bacteria to the intestinal niche: Probiotics and gut disorder. Inflamm. Bowel Dis. 2001, 7, 136-145. [CrossRef]

61. Windisch, W.; Kroismayr, A. The effects of phytobiotics on performance and gut function in monogastrics. In World Nutrition Forum: The Future of Animal Nutrition; Engormix: Buenos Aires, Argentina, 2016; pp. 85-90.

62. Gauthier, R. Poultry therapeutics: New alternatives in nuevas alternativas en therapeutica aviar. In Proceedings of the XVIII Latin American Poultry Congress, Santa Cruz, Bolivia, 7-2003;10 October 2003.

63. Abdel-Hafeez, H.M.; Saleh, E.S.; Tawfeek, S.S.; Youssef, I.M.; Abdel-Daim, A.S. Effects of probiotic, prebiotic, and synbiotic with and without feed restriction on performance, hematological indices and carcass characteristics of broiler chickens. Asian Australas. J. Anim. Sci. 2017, 30, 672. [CrossRef]

64. Riad, S.; Safaa, H.; Mohamed, F. Influence of probiotic, prebiotic and/or yeast supplementation in broiler diets on the productivity, immune response and slaughter traits. J. Anim. Poult. Prod. 2010, 1, 45-60.

65. Rosen, G. Holo-analysis of the efficacy of Bio-Mos ${ }^{\circledR}$ in broiler nutrition. Br. Poult. Sci. 2007, 48, 21-26. [CrossRef]

66. Yang, Y.; Iji, P.; Kocher, A.; Mikkelsen, L.; Choct, M. Effects of mannanoligosaccharide on growth performance, the development of gut microflora, and gut function of broiler chickens raised on new litter. J. Appl. Poult. Res. 2007, 16, 280-288. [CrossRef]

67. Ferket, P.R. Practical use of feed enzymes for turkeys and broilers. J. Appl. Poult. Res. 1993, 2, 75-81. [CrossRef]

68. Salamkhan, A.; Khalique, A.; Pasha, T. Effect of dietary supplementation of various levels of Fermacto on the performance of broiler chicks. Int. J. Agric. Biol. 2000, 2, 32-33.

69. Panda, A.; Raju, M.; Rama Rao, S.; Sharma, S. The influence of supplementation of lactobacillus sporogenes on the performance of broilers. Indian J. Anim. Nutr. 2005, 22, 37-40.

70. Banday, M.; Risam, K. Growth performance and carcass characteristics of broiler chicken fed with probiotics. Indian J. Poult. Sci. 2001, 36, 252-255.

71. Kabir, S.; Rahman, M.M.; Rahman, M.; Rahman, M.; Ahmed, S. The dynamics of probiotics on growth performance and immune response in broilers. Int. J. Poult. Sci. 2004, 3, 361-364.

72. Sarangi, N.R.; Babu, L.; Kumar, A.; Pradhan, C.; Pati, P.; Mishra, J. Effect of dietary supplementation of prebiotic, probiotic, and synbiotic on growth performance and carcass characteristics of broiler chickens. Vet. World 2016, 9, 313. [CrossRef]

73. Jin, L.; Ho, Y.; Abdullah, N.; Jalaludin, S. Growth performance, intestinal microbial populations, and serum cholesterol of broilers fed diets containing Lactobacillus cultures. Poult. Sci. 1998, 77, 1259-1265. [CrossRef]

74. Mehaffey, J.; Pradhan, S.; Meullenet, J.; Emmert, J.L.; Owens, C. Meat quality evaluation of minimally aged broiler breast fillets from five commercial genetic strains. Poult. Sci. 2006, 85, 902-908. [CrossRef]

75. Fletcher, D.; Qiao, M.; Smith, D. The relationship of raw broiler breast meat color and $\mathrm{pH}$ to cooked meat color and pH. Poult. Sci. 2000, 79, 784-788. [CrossRef] 
76. Al-Owaimer, A.N.; Suliman, G.M.; Alyemni, A.H.; Abudabos, A.M. Effect of different probiotics on breast quality characteristics of broilers under Salmonella challenge. Italian J. Anim. Sci. 2014, 13, 3189. [CrossRef]

77. Battula, V.; Schilling, M.; Vizzier-Thaxton, Y.; Behrends, J.; Williams, J.; Schmidt, T. The effects of low-atmosphere stunning and deboning time on broiler breast meat quality. Poult. Sci. 2008, 87, 1202-1210. [CrossRef] [PubMed]

78. Corzo, A.; Schilling, M.; Loar, R.; Jackson, V.; Kin, S.; Radhakrishnan, V. The effects of feeding distillers dried grains with solubles on broiler meat quality. Poult. Sci. 2009, 88, 432-439. [CrossRef] [PubMed]

79. Pelicano, E.R.L.; Souza, P.; Souza, H.; Oba, A.; Boiago, M.; Zeola, N.; Scatolini, A.; Bertanha, V.; Lima, T. Carcass and cut yields and meat qualitative traits of broilers fed diets containing probiotics and prebiotics. Braz. J. Poult. Sci. 2005, 7, 169-175. [CrossRef]

80. Hopkins, D.; Littlefield, P.; Thompson, J. A research note on factors affecting the determination of myofibrillar fragmentation. Meat Sci. 2000, 56, 19-22. [CrossRef]

81. Olson, D.G.; Stromer, M. Myofibril fragmentation and shear resistance of three bovine muscles during postmortem storage. J. Food Sci. 1976, 41, 1036-1041. [CrossRef]

82. Angelovicova, M.; Kral, M.; Vietoris, V.; Zidek, R. Effect of probiotics and thyme essential oil on the texture of cooked chicken breast meat. Acta Sci. Pol. Technol. Aliment. 2013, 12, 379-384.

83. Lisowski, M.; Lewandowska, M.; Bednarczyk, M.; Gulewicz, P.; Gulewicz, K. Prebiotic properties of pea alpha-galactoside preparation applied to chicken per os. Bull. Polish Acad. Sci. Biol. Sci. 2003, 51, 291-298.

84. Pelícia, K.; Mendes, A.; Saldanha, E.; Pizzolante, C.; Takahashi, S.; Garcia, R.; Moreira, J.; Paz, I.; Quinteiro, R.; Komiyama, C. Probiotic and prebiotic utilization in diets for free-range broiler chickens. Braz. J. Poult. Sci. 2004, 6, 99-104. [CrossRef]

(C) 2020 by the authors. Licensee MDPI, Basel, Switzerland. This article is an open access article distributed under the terms and conditions of the Creative Commons Attribution (CC BY) license (http://creativecommons.org/licenses/by/4.0/). 